\title{
衛星ステレオ画像データによる岩相区分図の自動作成
}

\author{
徳 永光 晴 ${ }^{*} 川$ 上亨 ${ }^{* *}$ 栘田彰 - ${ }^{* *}$
}

\section{Automated Creation of Lithofacies Classification Map using Satellite Stereo Images}

\author{
Mitsuharu ToKunAGA ${ }^{*}$, Toru KAWAKAMI ${ }^{* *}$ and Shoichi MASUdA ${ }^{* *}$
}

\section{I. はじめに}

地質図は資源探査において有用な基礎資料であるにもかかわらず，開発途上国をはじめ現地調查が困難 な地域においては整備されていない場合が多い。またこのような地域が，今後残された資源探査の有望地 域の多くを占めていると考兄られる。このため，これらの地域の地質図整備が資源探査ニーザーにより望 まれている。通常の地質図の作成では, 現地調査は欠くことのでさない重要な手段であり, 得られたデー タの解釈には専門家の豊富な経験や熟練等を要する。このため専門家の経験や熟練度等の違いにより解釈 の結果にばらつきが生じることがある。

本研究はこれらの状況を踏まえ, 地質図の整備が不十分な地域を対象とし, 地球観測衛星のデータから 自動的に地質図を作成することを目標とする。乙かし現地調査を行なわないことを前提とするため，地球 観測衛星データの久から岩石名を特定することは困難であると考光，地質図の作成よりも岩相区分図の作 成を当面の目標とする。特に，ここでは衛星のステレオ画像データから標高值を求め，その地形データか ら水系図を作成し，水系図から岩相区分図を作成する手法について述べる。

\section{II. 岩相区分方法}

岩相の自動区分の方法として, 写真地質学の専門家が衛星画像から判断, 解釈する過程をコンピュータ でシミュレートする方法が取り組みやすい。写真地質学の専門家は，地質解釈をする場合，主に次の要素 についての判読を行ない, それらを個別に, 又は総合的に解釈し, 岩石の分類を行なっている。したがっ て本研究では，これらの項目に関してそれぞれ単独に岩相の区分をし，最終的にそれらを組み合わせた， 総合的な岩相区分を行なら。

(1) 判読地域の特性

(2) 色 調

（3）水系のパターン特よび密度

（4）地形の起伏量叔よび高低差

(5) テクスチャ

（6）植生の分布叔よび密度

(7) 山稜と斜面の形態

これらの項目の中で（1）は，他の項目と異なり衛星画像から直接得られる情報ではなく，専門家の持つ 多くの経験や知識等により得られるものである。画像を解釈する際には，その対象地域の特性を専門家は

*セントラル・コンピュータ・サービス株式会社 * Central Computer Services Co., Ltd.

** 財団法人資源観測解析センター ** Earth Resources Satellite Data Analysis Center 
理解しており，これらの特性を加味しながら解釈を進めていく。その結果，専門家の経験や知識の相違に より解釈の結果が異なることもある。このように（1）の情報は分類項目として直接用いるのではなく，他 の項目を解析するときの知識ベースとして用いるものと位置付ける。（1）以外の項目は，衛星画像から得 ているものである。これらの項目について専門家がどのよらに判読を行なっているかの課程をそれぞれ調 査分析し，それぞれのアプローチによる区分図を作成する。

\section{III. 衛星データの利用}

地球観測衛星には数多くの種類があり，それぞれ色々な種類のセンサーが搭載されて和り利用目的が異 なる。資源探査に打いても同様に，利用目的により使用するデータを選択しなければならない。対象とす る地域が岩石の露出している地域であれば，LANDSAT TM に代表されるようなマルチスペクトルデー タを用い，岩石の吸収帯の違いにより岩相を区分することがある程度可能となる。対象とする地域が東南 アジアのような埴生が密な地域ではマルチスペクトルデータでは岩石の情報が得られないため, 地形情報 からのアプローチが必要となる。

一方，資源探査の対象地域は地形図も完備していないことが多いため地形情報を衛星データから算出し なくてはならない。衛星画像データにより対象地域のステレオ視が可能であれば空中三角測量の手法から 標高值は求めることがでさる。現在，ステレオ視が可能な衛星はフランスの打ち上げた SPOT に限られ ているため, SPOT データから標高値を算出し，それを地形データとして利用する。

前章で述べた専門家による判読項目と衛星データは，色調と植生の分布および密度がマルチスペクトル データの組み合わせに対応し，水系のパターン执よび密度，地形の起伏量特よび高低差，テクスチャ，山

稜と斜面の形態などが地形情報と対応する。

このようにマルチスペクトルデータと地形情報データのそれぞれからのアプローチを検討し，それらを 総合した区分図の作成フローを図 1 に示す。点線内は本報告の記述範囲を示す。

\section{IV. 水系区分図の作成}

水系とは水の流路のことであり，実際に水が流れているかいないかには関係しない。つまり山岳部に特

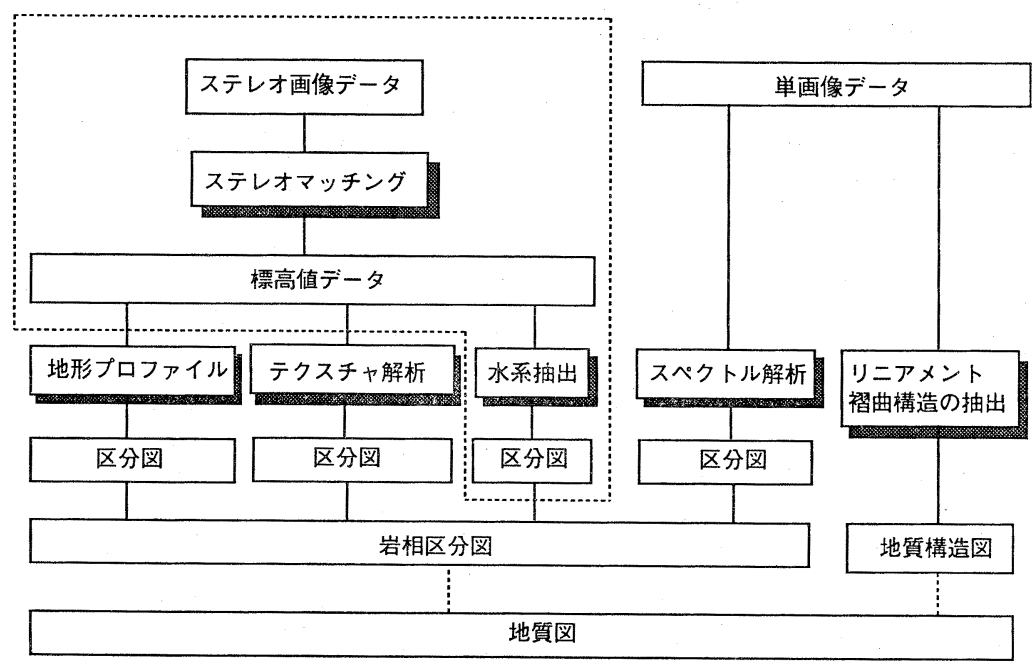

図 1 地質図作成全体フロー 


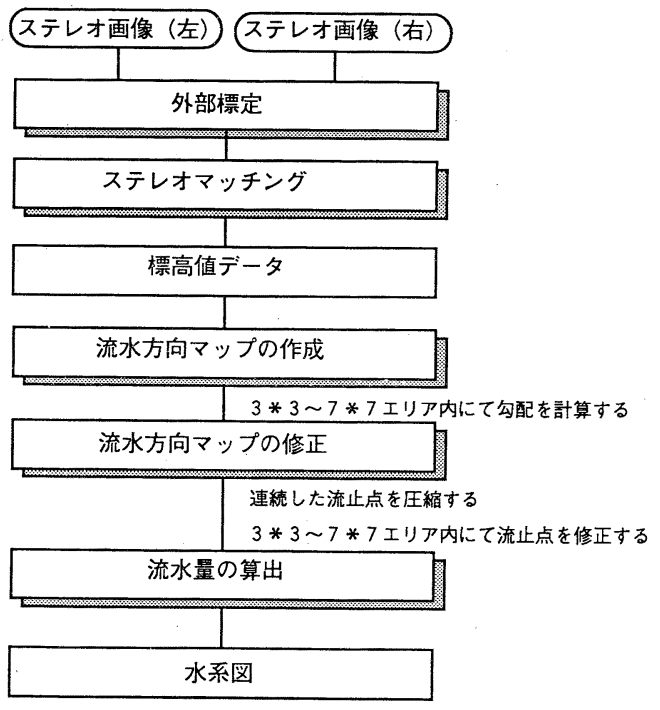

図 2 水系自動抽出処理フロー
いては山の谷線部を示し, 平野部においては河 川またはその枯れた軌跡となる。水系のパター ン拈よび密度は地形の性質を反映して和り，地 質とも密接な関係があることが経験的にわかっ ている。しかし, ある岩石が必ず同じ水系パタ ーンになるわけではなく, その地域の気候や侵 食ステージや地質時代により変化する。一方あ る地域に揖いて水系のパターンや密度が異なれ ば多くの場合岩種が異なることから, 水系のパ ターンと密度から岩種名を特定することはでき ないが岩相の区分は可能となる。このように水 系区分図は地質の分類に有効な情報となる。

\section{1）水系図の自動作成}

現在, 水系図は人手により画像をトレースす ることにより作成され，その判読には経験と知 識を要する。その作業量もかなり多くのものに なるため，水系図を自動作成する意義は大き い。

水系を抽出する方法として, 画像データに基づく方法と地形データに基づく方法がある。画像データに 基づく方法は，エッジ強調などによるェンハンスメント処理によるもので，平野部に拈いて効果がある。 地形データに基づく方法は水の流水方向を用いたもので山岳地带で効果がある。資源探査の対象地域が山 岳地帯に多いことから，ここでは地形データによる方法について述べる。

水系図の作成には基本的に「水は最大傾斜方向に流れる」といら論理を利用する。それだけでは SPOT 衛星画像から求めた地形データなどには誤差やノイズを含んでいるため，水系が途切れることが想像でき る。水系図は次のステップに衫いて定量化されることから，途切れずに連続的なものであることが望まし い。このためノイズや誤差等に影響されず連続的になるように図 2 に示すフローチャートにより水系の自 動抽出処理を行なう。次にその主な処理内容について記す。

(1) 標高值の算出

衛星の位置および姿勢を，衛星に記録されている軌道データと地上基準点から算出する。この処理を写 真測量学では外部標定と呼んでいる。つぎに面積相関法によりステレオ画像の対応点を求める。衛星の位 置执よび姿勢とステレオ画像の対応点が求まれば, 次の式から標高值 $(\mathrm{X}, \mathrm{Y}, \mathrm{Z})$ が算出される。

$$
\begin{aligned}
& X=X_{0}+\left(Z-Z_{0}\right) *\left(a_{1} x+a_{2} y-a_{3} f\right) /\left(a_{7} x+a_{8} y-a_{9} f\right) \\
& Y=Y_{0}+\left(Z-Z_{0}\right) *\left(a_{4} x+a_{5} y-a_{6} f\right) /\left(a_{7} x+a_{8} y-a_{9} f\right)
\end{aligned}
$$

ここで衛星の位置を $\mathrm{X}_{0}, \mathrm{Y}_{0}, \mathrm{Z}_{0}$, 姿勢を $\omega, \phi, \kappa$, センサーの画面距離を $\mathrm{f}$, 画像の写真座標を $\mathrm{x}, \mathrm{y}$ とし, $\mathrm{a}_{1} \sim \mathrm{a}_{9}$ を次の通りとする。

$$
\left(\begin{array}{lll}
a_{1} & a_{2} & a_{3} \\
a_{4} & a_{5} & a_{6} \\
a_{7} & a_{8} & a_{9}
\end{array}\right)=\left(\begin{array}{llr}
1 & 0 & 0 \\
0 \cos \omega & -\sin \omega \\
0 \sin \omega & \cos \omega
\end{array}\right)\left(\begin{array}{rrr}
\cos \kappa & -\sin \kappa & 0 \\
\sin \kappa & \cos \kappa & 0 \\
0 & 0 & 1
\end{array}\right)\left(\begin{array}{rlr}
\cos \phi & 0 & \sin \phi \\
0 & 1 & 0 \\
-\sin \phi & 0 & \cos \phi
\end{array}\right)
$$

(2) 流水方向マップの作成

正万格子の標高值データ各点に対しその点から水の流机る方向を算出し，流水方向マップを作成する。 注目している点の近隣の $3 * 3$ エリア 8 点に対し最急勾配方向を算出し，その方向を流水方向とする。流 水方向が決定できなかった場合，勾配の算出範囲を $5 * 5,7 * 7$ と広げ流水方向を決定する。 
（3）流水方向マップの修正

流水方向マップの作成に拈いて流水方向が決定されなかった点に対し，周囲の流水方向が同じような方 向に流れている場合，その点の流水方向を周囲の方向と同じ方向とする。この処理により水系が途切れる ことなく連続的になる。

(4) 流水量の算出

正方格子の各地点を通過する流水量を算出する。はじめに正方格子の標高値データ各点に対し初期值を 与光, 流水方向に添って水量を加算する。この処理を流止点まで繰り返す。ここで各点の流水量はその点 より上流の流域面積と等しくなる。

(5) 水系図の作成

水系の下流に行くに従って流水量は増えていく。流水量を閾値にすれば, 規模の異なる水系の区分が行 なえ，支流部と幹線部の水系を区分することもでさる。

以上の処理により，閾值を変えた自動作成水系図の例を図 3 ～図 5 に示す。自動作成した水系図は，前 述したような地質図の整備が不十分な地域での資源探査において，実用的な利用が可能な精度が得られた と判断される。

2) 水系パターン分類

水系のパターンは多種多様であるが，その基本形を樹枝状，平行状，格子状，直方状，放射状，環状の 6 種類に定義する。これらの典型的な形状を示す地域を選択し，それぞれの特徵量を求める。算出された 特徴量により水系パターンの定量化を行ない水系を区分する。

(1) 特徵量の種類

水系パターンを次の特徵量によりあらわす。入力するデータは前節で自動作成した水系データを用い る。

(a) 流水量別流水方向ヒストグラム

水系の支流部と幹線部の流水方向の違いをローズダイアグラムで示す。支流部と幹線部は流水量によっ

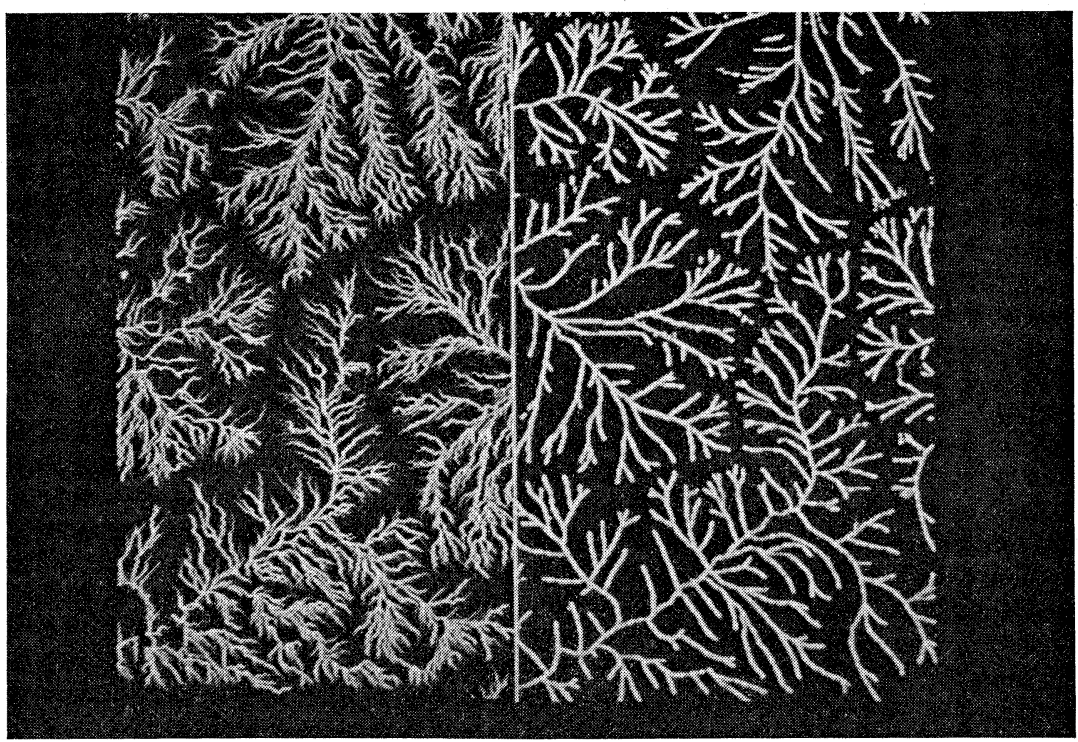

SPOT 衛星より自動作成 $1 / 2.5$ 万地形図より人手により作成

図 3 自動作成水系図 


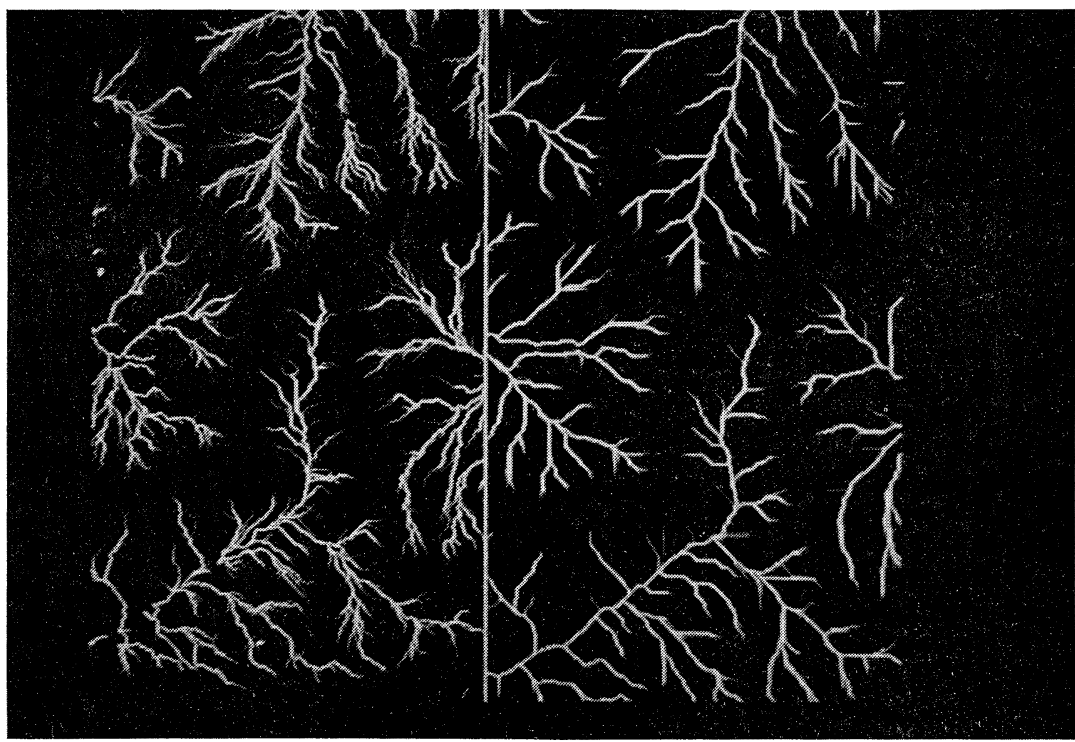

SPOT 衛星より自動作成

$\mathrm{DEM} よ り$ 自動作成

図 4 自動作成水采図

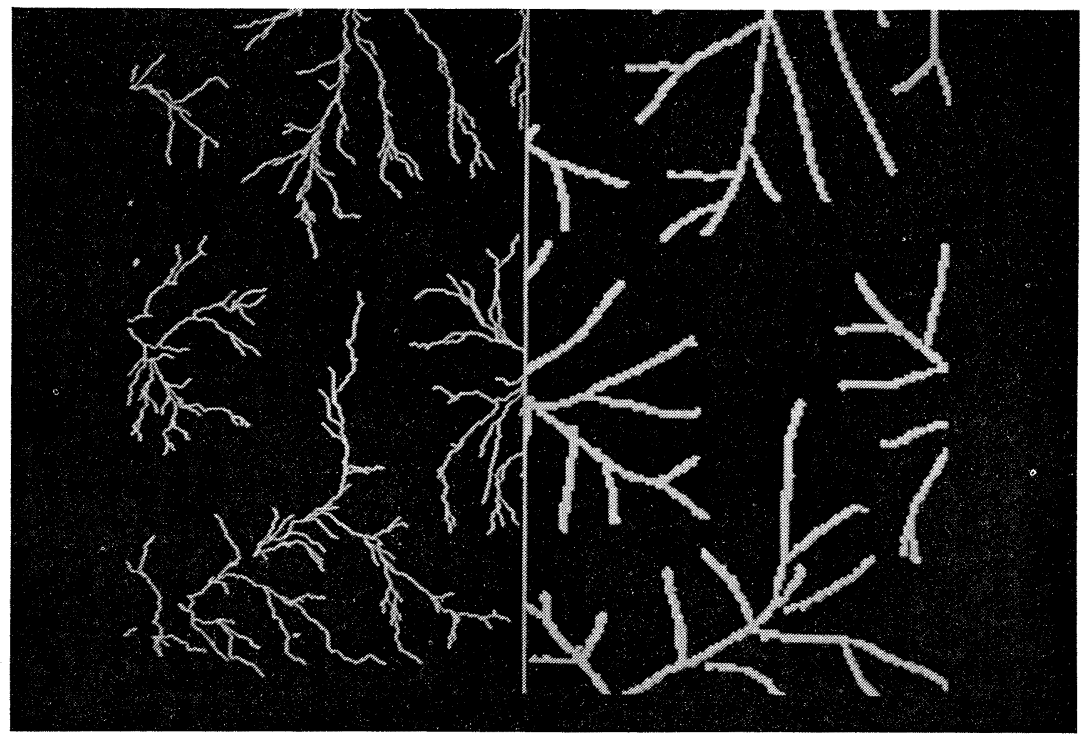

SPOT 衛星より自動作成

$1 / 20$ 万地形図より人手により作成

図 5 自動作成水系図

て区別する。

（b）流域面積の形状

形状 $1=$ =流域面積 /流域面積の周長 


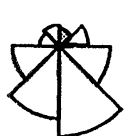

流水量(小)

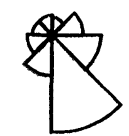

流水量(大)

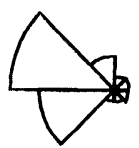

流水量(小) 流水量(大)

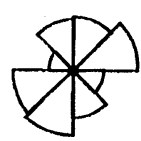

流水量(小) 流水量(大)

樹枝状

平行状

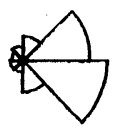

格子状

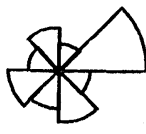

流水量(小)

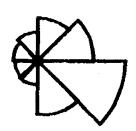

流水量(大)

直方状
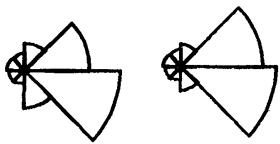

流水量(小) 流水量(大)

放射状

図 6 流水量別流水方向ヒストグラム

表 1 水系パターンの特徴量

\begin{tabular}{|c|c|c|c|c|c|c|}
\hline & & 樹枝状 & 平行状 & 格子状 & 直方状 & 放射状 \\
\hline (a) & 形状 $1 （ \mathrm{~A} / \mathrm{L})$ & 22.79 & 16.02 & 23.59 & 44.60 & 13.27 \\
\hline (b) & 形状 $2\left(\mathrm{~L}^{2} / \mathrm{A}\right)$ & 24.66 & 41.27 & 17.66 & 17.20 & 43.75 \\
\hline (c) & 密度（\%） & 13.05 & 9.10 & 6.41 & 5.00 & 13.89 \\
\hline (d) & 起伏量 & 0.0313 & 0.0349 & 0.1044 & 0.1124 & 0.2226 \\
\hline $\begin{array}{l}(\mathrm{e}) \\
(\mathrm{f})\end{array}$ & $\begin{array}{l}\text { 流水方向変化率（\%) } \\
\text { 流水量別 }\end{array}$ & 1.17 & 0.54 & 5.51 & 2.01 & 0.87 \\
\hline & 流水量（小） & 43.36 & 82.00 & 13.73 & 28.47 & 52.45 \\
\hline & 流水量（大） & 50.15 & 97.57 & 19.18 & 36.74 & 61.88 \\
\hline
\end{tabular}

形状 $2=(\text { 流域面積の周長 })^{2} /$ 流域面積 流域面積が細長い形をしているか丸まってい る形をしているかの形状を示す。流域面積は注 目点の流水量と等しく, 流域面積の周長は次の 方法で求めることができる。注目点から左方向 の上流点を尾根に到達するまで探索し，その経 路の長さを求める。同様に右方向に执いてもそ の長さを求める。次に左方向から探索した尾根 点と右方向から探索した尾根点との距離を尾根 に沿って求める。これらの長さの合計を流域面 積の周長とする。

(c) 水系密度

密度 $=$ 対象エリアの中である流水量以 上の点の総和／対象エリアの面 積

（d）起伏量

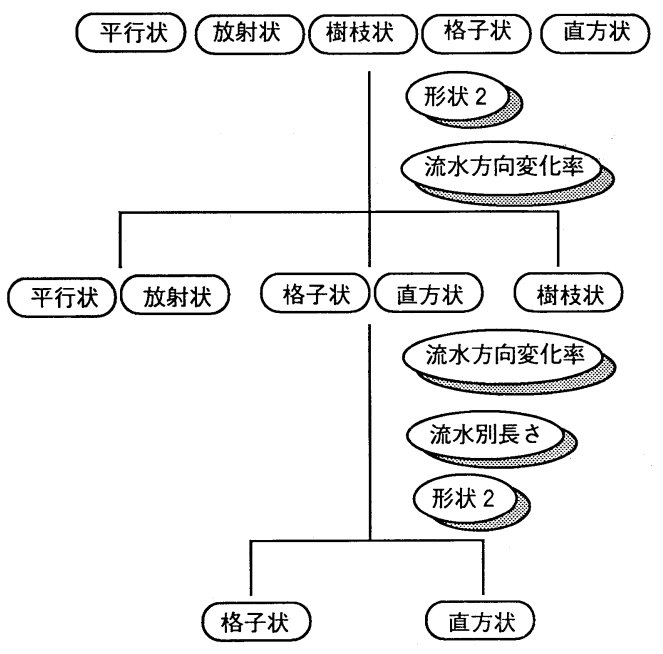

図 7 水系パターンの区分フロー 


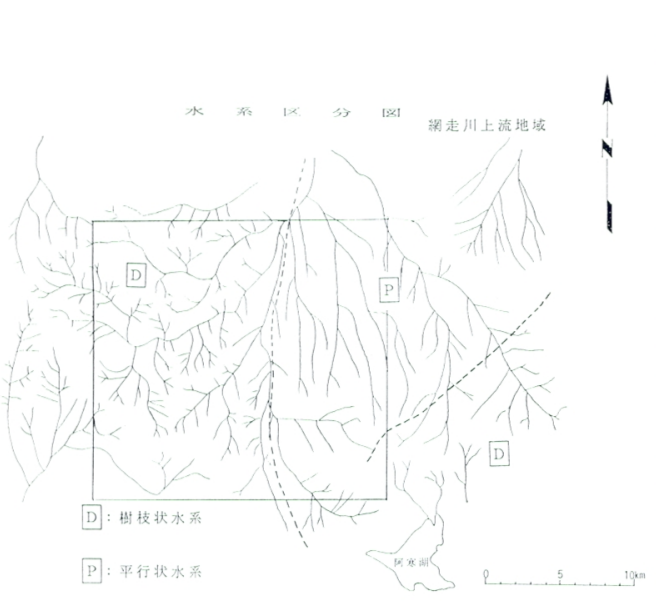

(a)人手により区分した水系図

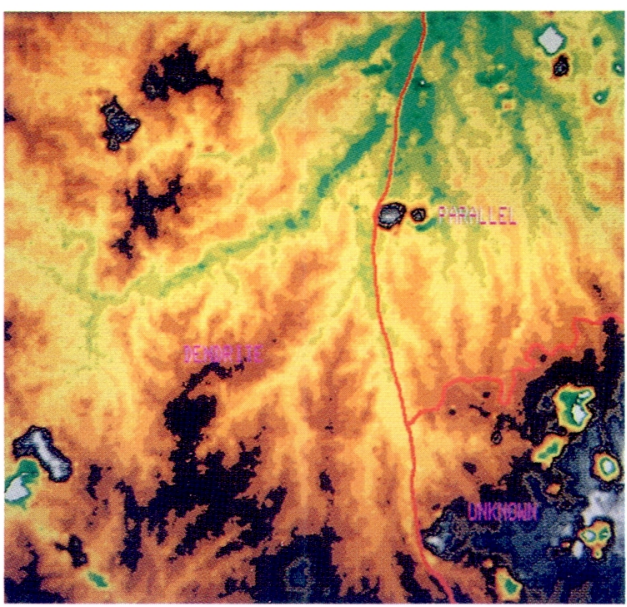

（b）自動区分した水系図

図 8 水系区分図

起伏量 $=($ 流域面積内の最高標高值 - 注目点の標高值 $) /$ 最高標高值点からの距離 水系の流机ている流域の傾斜の緩急を示す。

(e ) 流水方向変化率

変化率=チェーン符号の変化が 2 以上の点 $\left(90^{\circ}\right.$ 以上水系が曲がる点) /変化が 2 以上である点 直角以上飞流水方向が変化する割合を示す。

(f) 流水量別水系の長さ

水系の支流部之幹線部の長さの相違を求める。

(2) 水系パターンの分類結果

図 6 と表 1 亿水系パターンの特徴量の算出結果を示す。またこの算出結果から四 7 のフローに示す通り 水系パターンを区分することが可能となった。ただし今回の特徵量だけでは平行状と放射状の区別ができ なかったため，新たと流域の方向を示寸特徵量が必要であることがわかった。

手法の検証として平行状と樹枝状の発達する地域を選定し，水系パターンの自動区分を行なった。図 8

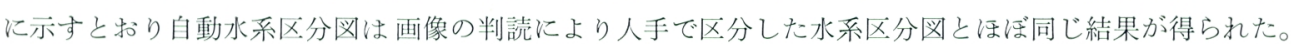
な䊉今回は，対象地域が 2 種の水系パターンのみであったため，今後の課題として他の水系パターンを含 も各種の水系の区分についても処理を行ないアルゴリズムの検証を行なう必要がある。

\section{V.おわりに}

水系図や岩相区分の結果は標高値の精度に依存するため, 衛星から求める標高値の精度が向上すれば精 度が上がる。現在の SPOT 画像データから算出される標高值は, 標準誤差で10数 $\mathrm{m}$ の精度を有し, この 精度は $40 \mathrm{~m}$ コンターつまり 10 万分の 1 の地形図の作成が可能であることを示している。今後この SPOT を上回る仕様を持つ衛星の打ら上げが予定されているため標高值算出の精度の向上が期待され，上り実用 的なものになると予想される。

今回報告した水系による岩相区分は, 図1飞示したと抢り本研究全体のなかの一部分である。今後さら 飞衛星データからの岩相分類の研究を進め, また地質構造の抽出手法を開発し, 総合的な地質図作成の手 法を開発する予定である。 
な和本研究は，昭和63年度特よび平成元年度の「石油資源遠隔探知技術の研究開発」の一環として行な われたものである。

\section{文献}

徳永・岩下・桝田・村井 (1988)：SPOT によるDTM を用いた水系自動抽出処理，日本写真測量 学会, 年次学術講演会論文集.

徳永・村井・岩下・桝田（1989）：DTM による水系パターン分類（その1），日本写真測量学会， 秋季学術講演会論文集.

村井俊治 (1987)：スポットHRV による地形計測，写真測量とリモートセンシング，特集号 1 .

(1990年10月17日受理) 